\title{
ANALISA SEBARAN TEKANAN AIRTANAH PADA CEKUNGAN AIRTANAH BRANTAS DAN UPAYA KONSERVASI DI KOTA BLITAR PROVINSI JAWA TIMUR
}

\author{
Mario Thadeus ${ }^{1}$, Mohammad Sholichin ${ }^{2}$, Runi Asmaranto ${ }^{2}$ \\ ${ }^{1}$ Mahasiswa Program Magister Teknik Jurusan Pengairan Universitas Brawijaya \\ ${ }^{2}$ Dosen Teknik Pengairan Fakultas Teknik Universitas Brawijaya \\ e-mail : $\underline{\text { mR.0512@rocketmail.com }}$
}

\begin{abstract}
Abstrak: PDAM Kota Blitar memiliki 19 sumur bor yang digunakan untuk pemenuhan kebutuhan air baku masyarakat Kota Blitar. Saat ini, hanya 6 sumur bor yang masih berfungsi yaitu SD 5, SD 10, SD 14, SD 17, SD 18, sedangkan 13 sumur lainnya sudah tidak berfungsi karena terjadi penurunan muka airtanah yaitu SD 1, SD 2, SD 3, SD 4, SD 6, SD 7, SD 8, SD 9, SD 11, SD 12, SD 13, SD 15, dan SD 16.

Penelitian mengenai penurunan muka airtanah pada daerah studi menggunakan analisa FEMWATER pada paket program Groundwater Modelling System (GMS) 4.0. dimana output dari program GMS 4.0. adalah sebaran nilai pressure head, total head, dan kedalaman muka airtanah. Simulasi yang dilakukan pada penelitian ini adalah simulasi tiap periode pembangunan sumur bor, simulasi kemampuan sumur bor untuk memenuhi kebutuhan air baku di Kota Blitar hingga tahun 2029, dan simulasi untuk mencari debit optimal dari masing-masing sumur bor yang sebaiknya dikeluarkan.

Pada periode pembangunan sumur bor tahun 1996, sebaran pressure head dan total head serta kedalaman muka airtanah pada sumur SD 1, SD 2, SD 3, dan SD 4 berada pada kedalaman yang mendekati screen bawah sumur sehingga menyebabkan tidak berfungsinya lagi keempat sumur tersebut. Penurunan kedalaman muka airtanah tersebut terjadi akibat adaya pembangunan sumur baru yaitu sumur SD 7 dan SD 8. Untuk pemenuhan kebutuhan air di tahun 2029, diambil asumsi sumur yang sudah tidak berfungsi lagi dapat diperbaiki dan difungsikan kembali. Dari 13 sumur yang rusak, hanya 10 sumur yang dapat diperbaiki, 3 lainnya tidak dapat diperbaiki karena lubang sumur yang sudah tidak ada. Hasil simulasi menunjukan, terdapat 10 sumur yang memiliki nilai pressure head di bawah screen bawah sumur yaitu sumur SD 1, SD 8, SD 9, SD 12, SD 13, SD 14, SD 15, SD 16, SD 18, dan SD 20. Tentunya membutuhkan tindakan konservasi terhadap airtanah sedini mungkin yaitu pengamanan daerah resapan sebagai daerah imbuhan di bagian hulu pada daerah studi.
\end{abstract}

Kata kunci: Kedalaman muka airtanah, ketinggian tekanan, ketinggian total, GMS 4.0.

Abstract: PDAM in Blitar city has 19 pumping wells which is used to fulfill the needs of water in Blitar City. Currently, only 6 wells are still working, namely SD 5, SD 10, SD 14, SD 17, SD 18, while 13 other wells are not working due to the decrease of groundwater level that are $S D 1, S D 2$, $S D$ 3, $S D$ 4, $S D$ 6, $S D$ 7, $S D$ 8, SD 9, SD 11, SD 12, SD 13, SD 15, and SD 16.

Research on decrease of groundwater level in the study area using FEMWATER analysis in the Groundwater Modeling System (GMS) program package 4.0. where the output of the program is GMS 4.0. is the distribution of pressure head, total head, and groundwater depth. There are 3 simulations done in this research are 1. Simulation of each pumping well development period, 2. Simulation of pumping well capability to meet the raw water needs in Blitar City until 2029, and 3. Simulation to find the optimal discharge of each pumping wells that should be issued.

During the period of 1996 pumping wells development, the distribution of pressure head, total head and groundwater depth at wells of $S D$ 1, SD 2, SD 3, and SD 4 were at depth near the bottom of the well screen causing the failure of the four wells. The decrease of groundwater level is caused by the construction of new wells namely SD 7 and SD 8 wells. For the fulfillment of water needs in 2029, the assumptions of wells that are no longer working can be repaired and re-worked. From the 13 damaged wells, only 10 repairable wells, the other 3 can not be repaired because the wellbore is 
gone. The simulation results show that there are 10 wells that have pressure head value below the bottom well screen are SD 1, SD 8, SD 9, SD 12, SD 13, SD 14, SD 15, SD 16, SD 18, and SD 20. Certainly requires conservation measures on groundwater as early as possible that is securing the recharge area as an upstream in the study area.

Keywords: Groundwater depth, pressure head, total head, GMS 4.0.

Airtanah sebagai salah satu sumberdaya air saat ini telah menjadi permasalahan nasional. Eksploitasi airtanah dari tahun ke tahun yang sangat pesat di berbagai sektor di Indonesia telah menuntut perlunya persiapan berupa langkah-langkah nyata untuk menanganinya, khususnya memperkecil dampak negatif yang ditimbulkannya. Perlu disadari, resiko dari eksploitasi airtanah secara berlebihan tentunya berdampak pada berkurangnya cekungan air tanah sehingga mengakibatkan menurunnya kualitas airtanah dikarenakan intrusi air laut, penurunan muka tanah, dan kekeringan.

Di Provinsi Jawa Timur khususnya di Kota Blitar, pemanfaatan airtanah digunakan untuk air baku. Namun beberapa tahun terakhir ini sumur-sumur bor yang dibangun oleh PDAM Kota Blitar untuk tujuan pemenuhan kebutuhan akan air baku banyak yang mengalami penurunan debit. Ini bisa jadi karena eksploitasi airtanah yang berlebihan dan tidak didukung dengan adanya upaya kebijakan mengenai pemanfaatan airtanah tersebut.

Pengelolaan airtanah harus didasarkan pada konsep pengelolaan cekungan airtanah (groundwater basin management). Terbatasnya pasokan air dari sumber air permukaan, ketergantungan yang tinggi terhadap airtanah, dan maraknya pengambilan sumber air karena tuntutan kebutuhan akan air yang terus menerus meningkat, memerlukan pengelolaan airtanah yang berwawasan lingkungan secara menyeluruh mencakup kegiatan untuk pelaksanaan konservasi airtanah dan pemantauan keseimbangan pemanfatannya.

\section{METODE PENELITIAN \\ Lokasi Penelitian}

Lokasi studi ini berada dalam wilayah administrasi Provinsi Jawa Timur yaitu pada Kota Blitar. Secara geografis, Kota Blitar terletak pada $112^{\circ} 7^{\prime}-112^{\circ} 28^{\prime}$ Bujur Timur dan $8^{\circ} 2^{\prime}-8^{\circ} 8^{\prime}$ Lintang Selatan, tepatnya berada di tengah wilayah Kabupaten Blitar. Kabupaten Blitar adalah satu-satunya kabupaten yang berbatasan langsung dengan
Kota Blitar karena posisi Kota Blitar berada ditengah wilayah Kabupaten Blitar.

Luas Kota Blitar adalah sebesar 3.257,85 ha atau $32,58 \mathrm{~km}^{2}$ yang terdiri dari 3 kecamatan dan 21 kelurahan. Kecamatan Sukerejo memiliki 7 kelurahan yaitu Tlumpu, Karangsari, Turi, Blitar, Sukorejo, Pakunden, dan Tanjungsari. Kecamatan Kepanjenkidul memiliki 7 kelurahan yaitu Kepanjenlor, Kepanjenkidul, Kauman, Bendo, Tanggung, Sentul, dan Ngadirejo. Kecamatan Sananwetan memiliki 7 kelurahan yaitu Rembang, Klampok, Plosokerep, Karangtengah, Sananwetan, Bendogerit, dan Gedog. Lokasi studi dapat dilihat pada gambar di bawah ini:

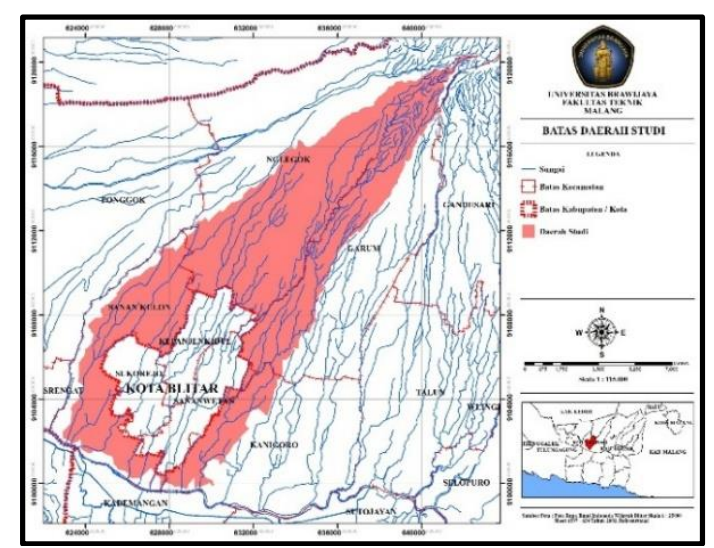

Gambar 1. Peta Batas Daerah Studi

Dari jumlah 19 sumur bor yang dimiliki PDAM Kota Blitar, 6 sumur bor yang masih berfungsi sampai saat ini dan 13 sumur sudah tidak berfungsi lagi. Ke 6 sumur itu adalah SD 5, SD 10, SD 14, SD 17, SD 18, dan SD 20 yang terletak pada Kelurahan Sentul, Kelurahan Gedog, Kelurahan Ngadirejo, Kelurahan Sananwetan. Sedangkan 13 sumur yang tidak berfungsi adalah SD 1, SD 2, SD 3, SD 4, SD 6, SD 7, SD 8, SD 9, SD 11, SD 12, SD 13, SD 15, dan SD 16 yang terletak di Kelurahan Sentul, Kelurahan Sananwetan, Kelurahan Pakunden, Kelurahan Ngadirejo, dan Kelurahan Bendogerit.

Tidak berfungsinya ke 13 sumur dikarenakan terjadi penurunan muka airtanah sehingga menyebabkan material pembawa air 
di dalam tanah yaitu tufa dan pasir memasuki lubang sumur dan menyebabkan screen sumur jebol dan rusak.

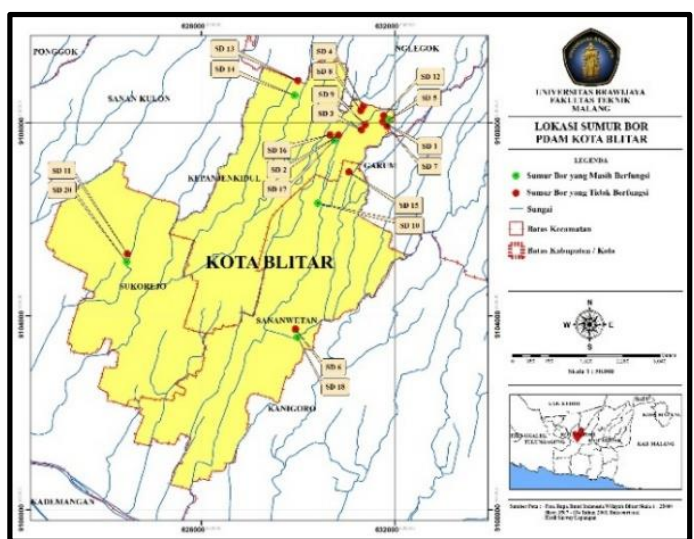

Gambar 2. Peta Lokasi Sumur Bor PDAM Kota Blitar

\section{Pressure Head (Ketinggian Tekanan)}

Dalam penelitian ini, pressure head merupakan batas tinggi muka airtanah sampai pada lapisan kedap air atau kedalaman sumur yang terjadi akibat adanya tekanan airtanah di dalam lubang sumur bor. Hal ini secara matematis dinyatakan sebagai berikut (Kodoatie RJ, 2012):

$\psi=\frac{\mathrm{P}}{\gamma}=\frac{\mathrm{P}}{\rho \mathrm{g}}$

dimana

$\psi$ adalah head tekanan (panjang, $\mathrm{m}$ )

$\mathrm{P}$ adalah cairan tekanan $(\mathrm{Pa})$

$\gamma$ adalah berat jenis $\left(\mathrm{N} / \mathrm{m}^{3}\right)$

$\rho$ adalah densitas fluida $\left(\mathrm{kg} / \mathrm{m}^{3}\right)$

$\mathrm{g}$ adalah percepatan gravitasi (laju perubahan kecepatan, $\mathrm{m} / \mathrm{dt}$ )

Perhatikan bahwa dalam persamaan ini, istilah tekanan mungkin tekanan gauge atau tekanan mutlak, tergantung pada desain wadah dan apakah terbuka untuk udara atau disegel tanpa udara.

\section{Total Head (Ketinggian Total)}

Total head (ketinggian total) merupakan nilai pressure head ditambahkan dengan nilai elevation head dimana elevation head adalah elevasi terendah pada lokasi penelitian $=0$. Hal ini diasumsikan bahwa pada muka airtanah terendah tekanan yang terjadi adalah $=0$ (otmospheric) dan ketinggiannya $=\mathrm{z}$, atau merupakan elevasi terendah $=0$ (Kodoatie RJ, 2012:97). Besaran tekanan airtanah dapat dihitung dengan menggunakan persamaan sebagai berikut (Kodoatie RJ, 2012):
$\mathrm{P}=\rho \mathrm{xgx} \psi+\mathrm{Po}$

$\mathrm{P}=\rho \times \mathrm{g} \times(\mathrm{h}-\mathrm{z})+\mathrm{Po}$

Sehingga besar potensi fluida:

$\phi=\mathrm{g} \times \mathrm{z}+\frac{\mathrm{P}-\mathrm{Po}}{\rho}=\mathrm{g} \times \mathrm{h}$

Dimana :

$\mathrm{h}=$ ketinggian total (total head)

$\psi=$ ketinggian tekanan (pressure head)

$\mathrm{z}=$ elevation head

$\mathrm{P}=\rho \mathrm{g} \psi=$ tekanan fluida

Po $=$ Tekanan Atmosfir

Untuk akuifer tertekan maka ketinggian hidrauliknya tidak lagi berupa muka air namun merupakan garis yang disebut sebagai potentiometric surface atau disebut pula permukaan piezometris. Garis ini merupakan garis imajiner bertepatan dengan ketinggian tekanan hidrostatis dari air dalam akuifer tertekan (Kodoatie RJ, 2012).

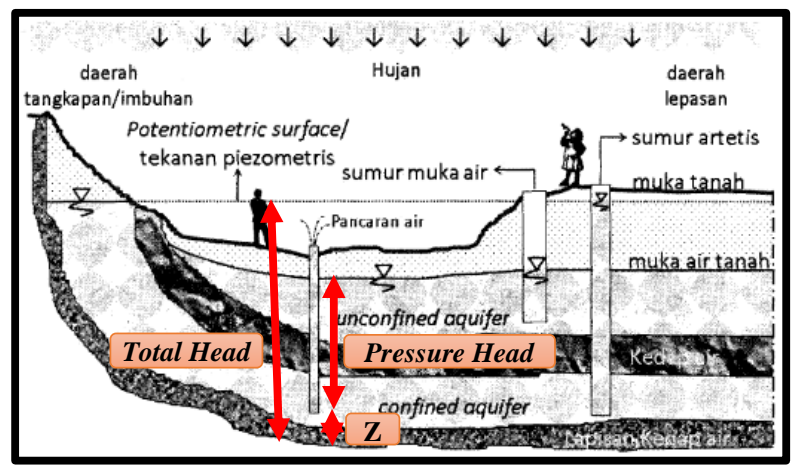

Gambar 3. Potentiometric Suface dari Sebuah Akuifer Tertekan

Sumber: Robert J. Kodoatie (2012)

\section{HASIL DAN PEMBAHASAN}

Proyeksi Jumlah Penduduk

Dari hasil perhitungan proyeksi jumlah penduduk Kota Blitar tahun 2010 sampai tahun 2014 didapatkan proyeksi jumlah penduduk ditabelkan sebagai berikut:

Tabel 1. Proyeksi Jumlah Penduduk Kota Blitar Tahun 2010 s/d Tahun 2014

\begin{tabular}{ccccc}
\hline \hline \multirow{2}{*}{ Tahun } & $\begin{array}{c}\text { Jumlah } \\
\text { Penduduk } \\
\text { (Jiwa) }\end{array}$ & Aritmatik & Geometrik & Eksponensial \\
\cline { 3 - 5 } & 140574 & 140694 & 140643 & 140626 \\
\hline \hline 2010 & 143218 & 141773 & 141747 & 141734 \\
\hline 2011 & 145300 & 142868 & 142860 & 142851 \\
\hline 2012 & 146602 & 143981 & 143981 & 143976 \\
\hline 2013 & 145111 & 145111 & 145111 & 145111 \\
\hline 2014 & $\mathbf{1 7 4 6}$ & $\mathbf{1 7 6 6}$ & $\mathbf{1 7 7 3}$ \\
\hline \hline Standar Deviasi & $\mathbf{0 . 8 3 6 7 9}$ & $\mathbf{0 . 8 3 9 1 6}$ & $\mathbf{0 . 8 3 9 1 5}$ \\
\hline Koefisien Korelasi & $\mathbf{0 1 9}$
\end{tabular}

Sumber: Kota Blitar dalam Angka Tahun 2015 dan hasil perhitungan 
Dalam menentukan metode proyeksi jumlah penduduk yang paling mendekati kenyataan di lapangan harus melihat standar deviasi dan koefisien korelasi seperti yang ditampilkan pada tabel di atas. Berdasarkan tabel di atas, metode aritmatik yang mendekati kenyataan di lapangan karena memiliki standar deviasi terkecil dan koefisien korelasi mendekati 1 . Metode tersebut akan digunakan untuk menghitung proyeksi jumlah penduduk Kota Blitar selama 15 tahun ke depan. Perhitungan proyeksi jumlah penduduk Kota Blitar hingga tahun 2029 atau 15 tahun kedepan menggunakan metode aritmatik seperti yang ditunjukan pada tabel di bawah ini:

Tabel 2. Proyeksi Jumlah Penduduk Kota Blitar Tahun 2015 s/d Tahun 2029

\begin{tabular}{ccc}
\hline \hline No. & Tahun & $\begin{array}{c}\text { Proyeksi Jumlah } \\
\text { Penduduk (Jiwa) }\end{array}$ \\
\hline \hline & 2014 & 145111 \\
\hline 1 & 2015 & 146250 \\
\hline 2 & 2016 & 147389 \\
\hline
\end{tabular}

\begin{tabular}{ccc}
\hline \hline No. & Tahun & $\begin{array}{c}\text { Proyeksi Jumlah } \\
\text { Penduduk (Jiwa) }\end{array}$ \\
\hline \hline 3 & 2017 & 148528 \\
\hline 4 & 2018 & 149667 \\
\hline 5 & 2019 & 150806 \\
\hline 6 & 2020 & 151945 \\
\hline 7 & 2021 & 153084 \\
\hline 8 & 2022 & 154223 \\
\hline 9 & 2023 & 155362 \\
\hline 10 & 2024 & 156501 \\
\hline 11 & 2025 & 157640 \\
\hline 12 & 2026 & 158779 \\
\hline 13 & 2027 & 159918 \\
\hline 14 & 2028 & 161057 \\
\hline 15 & 2029 & 162196 \\
\hline \hline
\end{tabular}

\section{Kebutuhan Air Bersih}

Data yang didapatkan dari hasil perhitungan proyeksi jumlah penduduk Kota Blitar pada tahun 2015 adalah sebesar 146250 jiwa, didapatkan kebutuhan air bersih masyarakat Kota Blitar dari tahun 2014 sampai tahun 2029 ditabelkan sebagai berikut:

Tabel 3. Kebutuhan Air Bersih Kota Blitar Tahun 2014, Tahun 2019, Tahun 2024, dan Tahun 2029

\begin{tabular}{|c|c|c|c|c|c|c|}
\hline \multirow{2}{*}{ No } & \multirow{2}{*}{ Uraian } & \multirow{2}{*}{ Satuan } & \multicolumn{3}{|c|}{ Tahun } & \multirow[b]{2}{*}{2029} \\
\hline & & & 2014 & 2019 & 2024 & \\
\hline 1 & Jumlah penduduk & jiwa & 145111 & 150806 & 156501 & 162196 \\
\hline 2 & Jumlah jiwa/rumah & jiwa & 5 & 5 & 5 & 5 \\
\hline 3 & Tingkat pelayanan & $\%$ & 100 & 100 & 100 & 100 \\
\hline 4 & $\begin{array}{l}\text { Jumlah penduduk berdasarkan tingkat } \\
\text { pelayanan }\end{array}$ & jiwa & 145111 & 150806 & 156501 & 162196 \\
\hline 5 & Kebutuhan air untuk tiap 1 orang per hari & lt/jiwa/hr & 150 & 150 & 150 & 150 \\
\hline \multirow[b]{2}{*}{6} & \multirow{2}{*}{ Kebutuhan air domestik } & $\mathrm{lt} / \mathrm{hr}$ & 21766650 & 22620900 & 23475149 & 24329399 \\
\hline & & $1 \mathrm{t} / \mathrm{dt}$ & 251.93 & 261.82 & 271.70 & 281.59 \\
\hline 7 & $\begin{array}{l}\text { Kebutuhan air non domestik (15\% dari } \\
\text { kebutuhan domestik) }\end{array}$ & $1 \mathrm{t} / \mathrm{dt}$ & 37.79 & 39.27 & 40.76 & 42.24 \\
\hline \multirow{2}{*}{8} & \multirow{2}{*}{ Kehilangan air $(15 \%)$} & $1 \mathrm{t} / \mathrm{dt}$ & 43.46 & 45.16 & 46.87 & 48.57 \\
\hline & & $\mathrm{m}^{3} / \mathrm{dt}$ & 0.0435 & 0.0452 & 0.0469 & 0.0486 \\
\hline \multirow{2}{*}{9} & \multirow{2}{*}{ Total kebutuhan air baku } & $\mathrm{lt} / \mathrm{dt}$ & 333.18 & 346.25 & 359.33 & 372.40 \\
\hline & & $\mathrm{m}^{3} / \mathrm{dt}$ & 0.3332 & 0.3463 & 0.3593 & 0.3724 \\
\hline
\end{tabular}

Sumber: Hasil perhitungan dan Departemen Pekerjaan Umum RI Ditjen Cipta Karya, 1994

\section{Perhitungan Infiltrasi}

Perhitungan besarnya nilai infiltrasi pada studi ini adalah dengan menggunakan Singlering Infiltrometer. Single-ring Infiltrometer yang digunakan berbentuk tabung berukuran diameter $21 \mathrm{~cm}$ dengan panjang $40 \mathrm{~cm}$.

Single-ring Infiltrometer ditancapkan kedalam tanah pada lokasi studi sedalam 3/4 dari alat tersebut atau $25 \mathrm{~cm}$ kemudian dimasukan air kedalamnya lalu dihitung penurunan muka air tersebut.

Penurunan muka air pada Single-ring Infiltrometer terjadi akibat adanya infiltrasi pada tanah. Hasil dari pengukuran di lokasi studi tersebut kemudian dihitung menggunakan rumus Horton sehingga dapat diketahui besarnya kapasitas infiltrasi yang terjadi pada lokasi studi.

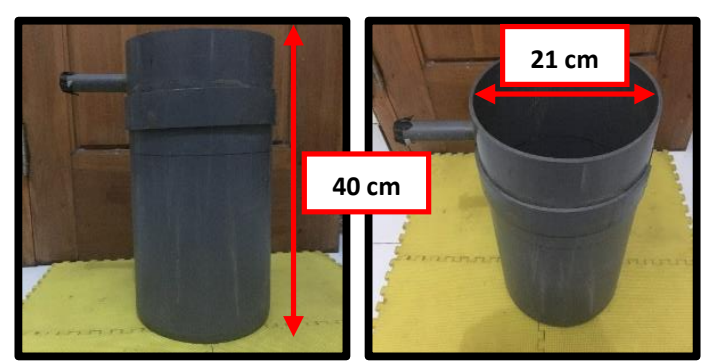

Gambar 4. Single-ring Infiltrometer 
Terdapat 5 titik lokasi penelitian menggunakan Single-ring Infiltrometer yang telah dilakukan pada lokasi studi dari tanggal 8 Juli 2017 sampai dengan tanggal 9 Juli 2017. Lokasi- lokasi tersebut adalah pada Kecamatan Nglegok dan Kecamatan Garum.

Besarnya kapasitas infiltrasi yang terjadi pada lokasi studi seperti pada tabel di bawah ini:

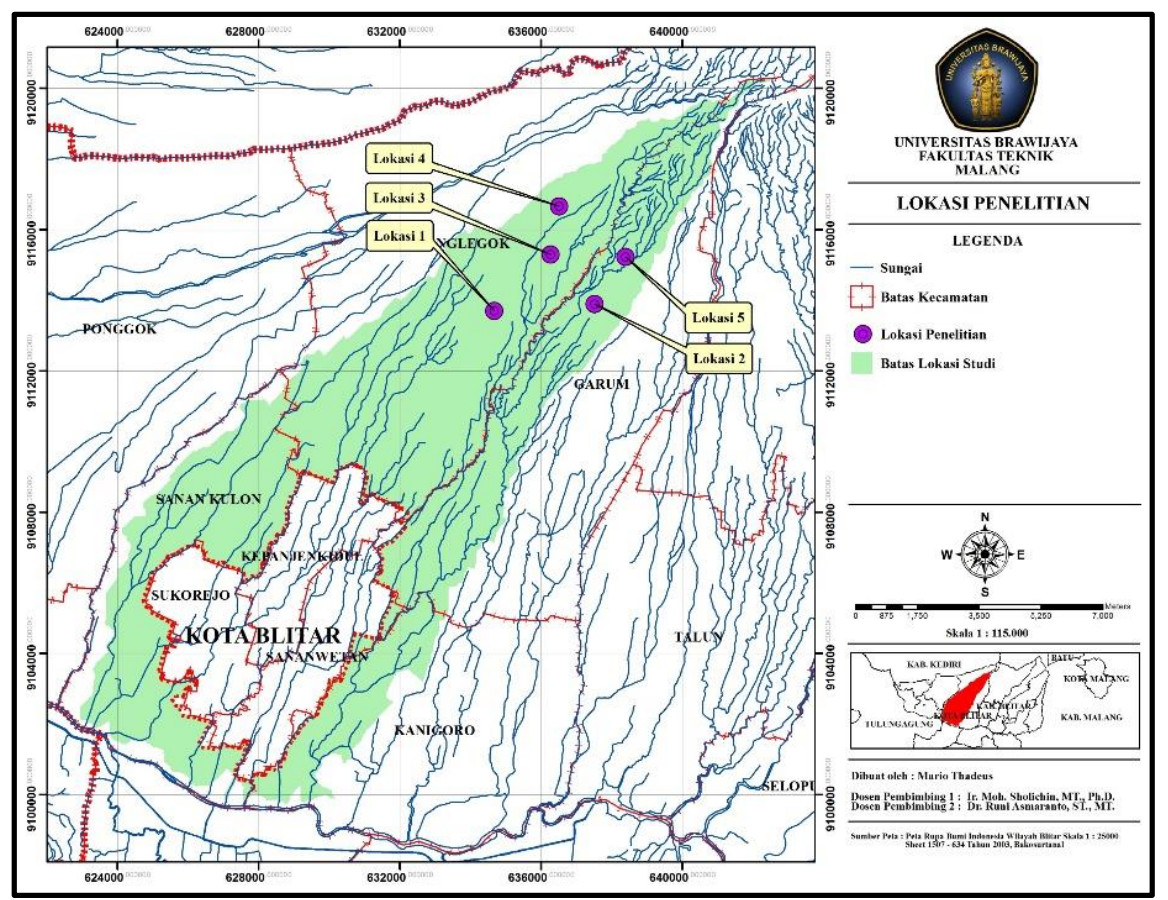

Gambar 5. Peta Lokasi Penelitian Menggunakan Single-Ring Infiltrometer

Tabel 4. Kapasitas Infiltrasi pada Lokasi Studi

\begin{tabular}{ccc}
\hline \hline Lokasi & $\begin{array}{c}\text { Kapasitas } \\
\text { Infiltrasi } \\
(\mathbf{F}) \\
(\mathbf{m} / \mathbf{d t})\end{array}$ & $\begin{array}{c}\text { Kapasitas } \\
\text { Infiltrasi } \\
(\mathbf{F}) \\
(\mathbf{c m} / \mathbf{j a m})\end{array}$ \\
\hline \hline Lokasi 1 & $9.0516 \times 10^{-6}$ & 3.25857 \\
\hline Lokasi 2 & $1.0834 \times 10^{-5}$ & 3.90041 \\
\hline Lokasi 3 & $1.4957 \times 10^{-5}$ & 5.38453 \\
\hline Lokasi 4 & $1.4031 \times 10^{-5}$ & 5.05127 \\
\hline Lokasi 5 & $1.4426 \times 10^{-5}$ & 5.19346 \\
\hline \hline Rata-Rata & $\mathbf{1 . 2 6 6 \times 1 0} \mathbf{1 0}^{-5}$ & $\mathbf{4 . 5 5 7 6 5}$ \\
\hline \hline Sumber: Hasil perhitungan
\end{tabular}

Kalibrasi Model GMS 4.0.

Saat ini di Kota Blitar, jumlah sumur bor yang masih berfungsi adalah 6 sumur yaitu SD 5, SD 10, SD 14, SD 17, SD 18, dan SD 20, sehingga untuk kalibrasi program GMS 4.0, digunakan keenam sumur tersebut. Namun kendala yang didapat di lapangan adalah sangat sulit mendapatkan data tinggi muka airtanah pada saat ini dikarenakan sumur yang masih beroperasi. Maka untuk kalibrasi model digunakan data tinggi muka airtanah pada saat dibangun dan didapatkan hasil sebagai berikut:

Tabel 5. Hasil Pemodelan Setelah Kalibrasi dibandingkan dengan Data Lapangan

\begin{tabular}{|c|c|c|c|c|c|c|c|c|c|}
\hline \multirow[b]{2}{*}{$\begin{array}{l}\text { Kode } \\
\text { Sumur }\end{array}$} & \multicolumn{2}{|c|}{ Debit } & \multirow{2}{*}{$\begin{array}{c}\text { Elevasi } \\
\text { Muka } \\
\text { Tanah } \\
(\mathbf{m}) \\
\end{array}$} & \multicolumn{2}{|c|}{ Kondisi Eksisting } & \multirow{2}{*}{$\begin{array}{c}\text { Muka } \\
\text { Airtanah } \\
\text { Eksisting } \\
(\mathbf{m}) \\
\end{array}$} & \multirow{2}{*}{$\begin{array}{c}\text { Muka } \\
\text { Airtanah } \\
\text { GMS 4.0 } \\
(\mathbf{m}) \\
\end{array}$} & \multirow[b]{2}{*}{$\begin{array}{c}\text { Nash-Sutcliffe } \\
\text { (NS Simulation } \\
\text { Efficiency) }\end{array}$} & \multirow[b]{2}{*}{$\begin{array}{c}\text { Kesalahan } \\
\text { Relatif } \\
(\%)\end{array}$} \\
\hline & $(\mathbf{l t} / \mathbf{d t})$ & $\left(\mathrm{m}^{3} / \mathrm{dt}\right)$ & & $\begin{array}{c}\text { Pressure } \\
\text { Head } \\
\left(\mathrm{mH}_{2} \mathrm{O}\right)\end{array}$ & $\begin{array}{c}\text { Total } \\
\text { Head } \\
\left(\mathrm{mH}_{2} \mathrm{O}\right)\end{array}$ & & & & \\
\hline SD 5 & 30 & 0.030 & 234.05 & 80.86 & 314.91 & 7.00 & 7.29 & -0.30 & 3.91 \\
\hline SD 10 & 25 & 0.025 & 207.88 & 89.19 & 297.07 & 6.00 & 6.34 & 0.80 & 5.30 \\
\hline SD 14 & 25 & 0.025 & 228.68 & 81.95 & 310.63 & 6.00 & 6.39 & 0.74 & 6.03 \\
\hline SD 17 & 25 & 0.025 & 224.91 & 95.94 & 320.85 & 6.80 & 6.92 & -0.46 & 1.69 \\
\hline SD 18 & 25 & 0.025 & 166.58 & 109.30 & 275.88 & 8.00 & 8.03 & 1.00 & 0.33 \\
\hline SD 20 & 25 & 0.025 & 168.20 & 107.53 & 275.73 & 6.70 & 6.72 & 0.88 & 0.26 \\
\hline \multicolumn{9}{|c|}{ Rata-rata } & 2.92 \\
\hline
\end{tabular}




\section{Simulasi Model GMS 4.0. Periode Pembangunan Sumur Bor}

1. Simulasi Model GMS 4.0. Periode Tahun 1996

Pada tahun 1996, sumur SD 3 sudah tidak berfungsi lagi pada tahun 1995 karena nilai pressure head yang berada sudah mendekati screen bawah sumur. Nilai pressure head yang terendah terjadi pada sumur SD 1 dengan nilai $1,66 \mathrm{mH}_{2} \mathrm{O}$ dan nilai pressure head tertinggi terjadi pada sumur SD 6 dengan nilai 73,15 $\mathrm{mH}_{2} \mathrm{O}$. Nilai total head yang terendah terjadi pada sumur SD 1 dengan nilai 234,51 $\mathrm{mH}_{2} \mathrm{O}$ dan nilai total head tertinggi terjadi pada sumur SD 5 dengan nilai $302,63 \mathrm{mH}_{2} \mathrm{O}$. Ratarata nilai pressure head adalah $42,59 \mathrm{mH}_{2} \mathrm{O}$ dan rata-rata nilai total head adalah 265,19 $\mathrm{mH}_{2} \mathrm{O}$. Kedalaman muka airtanah yang terendah terjadi pada sumur SD 5 dengan nilai $19,57 \mathrm{~m}$ dan kedalaman muka airtanah tertinggi terjadi pada sumur SD 4 dengan nilai $82,86 \mathrm{~m}$. Rata-rata kedalaman muka airtanah adalah $46,10 \mathrm{~m}$.

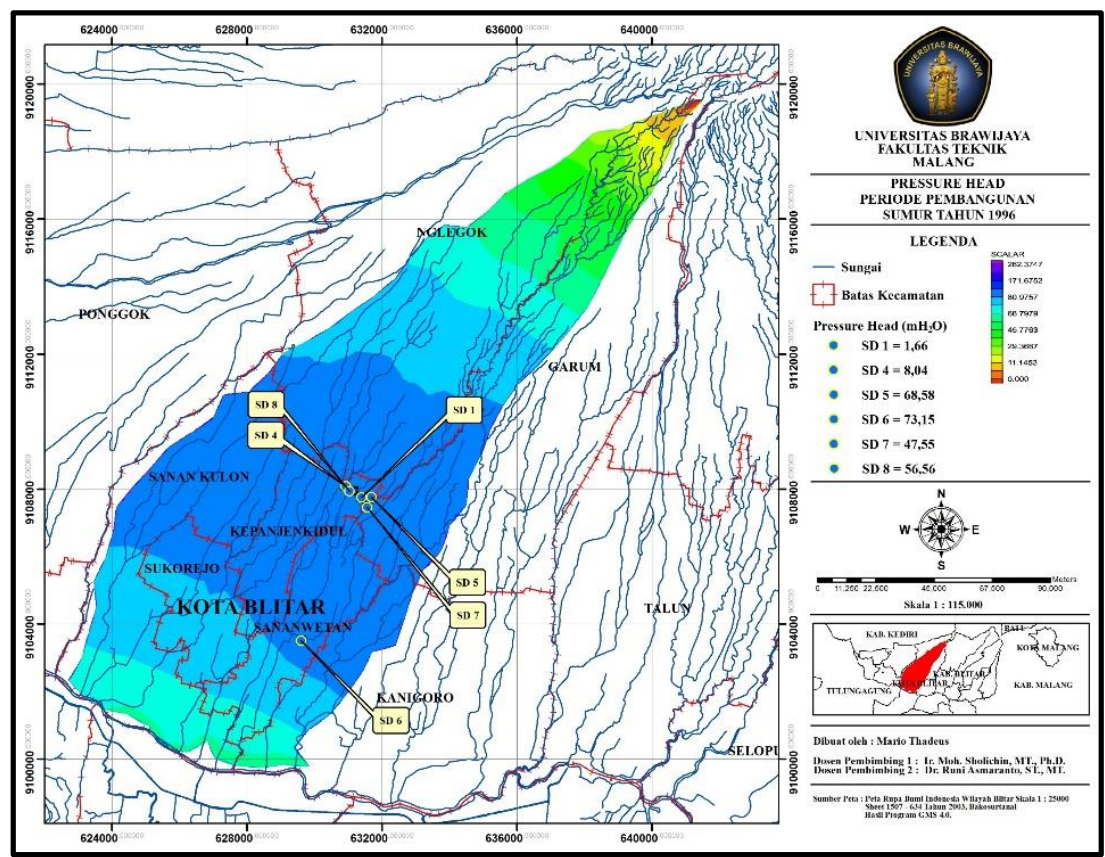

Gambar 6. Peta Sebaran Pressure Head Periode Tahun 1996

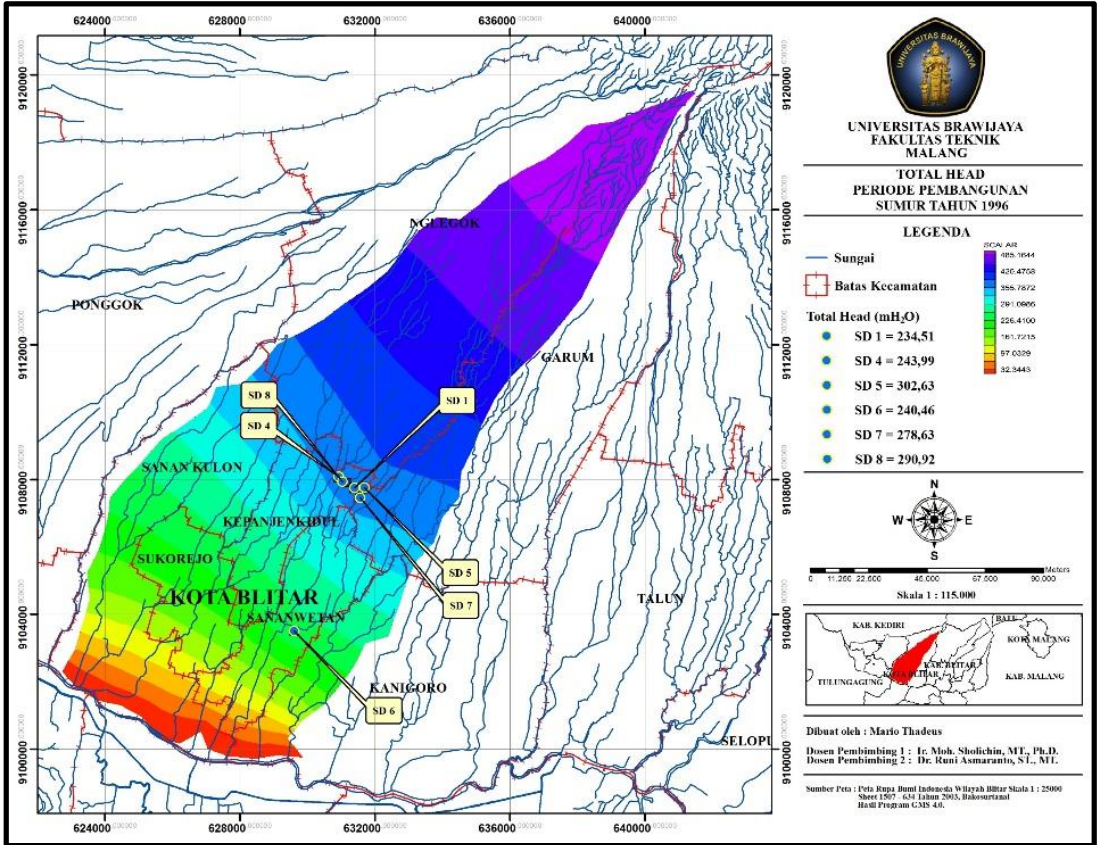

Gambar 7. Peta Sebaran Total Head Periode Tahun 1996 
2. Simulasi Model GMS 4.0. Periode Tahun 2009

Pada tahun 2009, sumur SD 9 dan SD 11 sudah tidak berfungsi lagi pada tahun 2006 karena nilai pressure head yang berada sudah mendekati screen bawah sumur. Nilai pressure head yang terendah terjadi pada sumur SD 12 dengan nilai $9,19 \mathrm{mH}_{2} \mathrm{O}$ dan nilai pressure head tertinggi terjadi pada sumur SD 20 dengan nilai $107,53 \mathrm{mH}_{2} \mathrm{O}$. Nilai total head yang terendah terjadi pada sumur SD 10 dengan nilai 239,33 $\mathrm{mH}_{2} \mathrm{O}$ dan nilai total head tertinggi terjadi pada sumur SD 17 dengan nilai $302,61 \mathrm{mH}_{2} \mathrm{O}$. Rata-rata nilai pressure head adalah 49,44 $\mathrm{mH}_{2} \mathrm{O}$ dan rata-rata nilai total head adalah 262,29 $\mathrm{mH}_{2} \mathrm{O}$. Kedalaman muka airtanah yang terendah terjadi pada sumur SD SD 20 dengan nilai $6,72 \mathrm{~m}$ dan kedalaman muka airtanah tertinggi terjadi pada sumur SD 12 dengan nilai 71,95 m. Rata-rata kedalaman muka airtanah adalah 47,71 m.

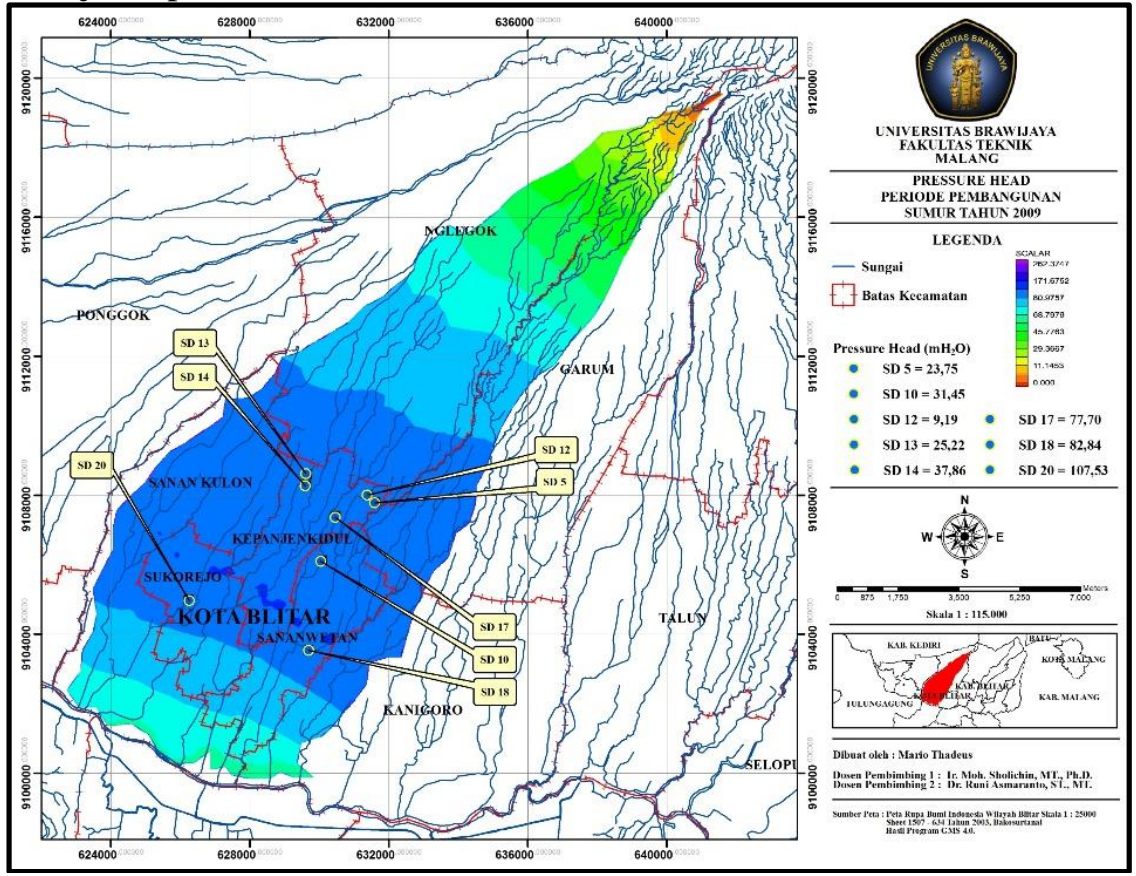

Gambar 8. Peta Sebaran Pressure Head Periode Tahun 2009

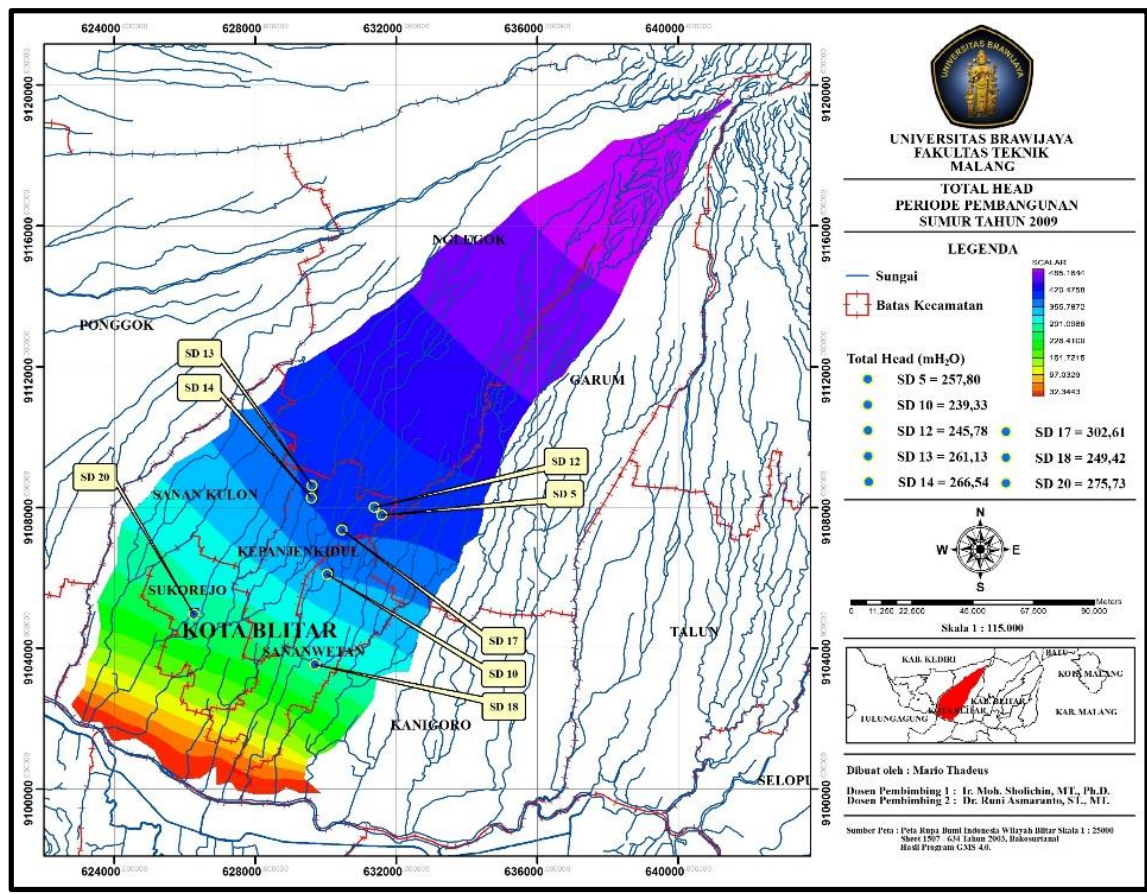

Gambar 9. Peta Sebaran Total Head Periode Tahun 2009 


\section{Simulasi Model GMS 4.0. Untuk} Pemenuhan Keb. Air Baku Tahun 2029

Pada simulasi model GMS 4.0. untuk pemenuhan kebutuhan air baku di Kota Blitar, diambil asumsi bahwa debit yang ditanggung tiap sumur adalah sama dan sumur yang sudah tidak berfungsi lagi dapat diperbaiki dan difungsikan kembali. Dari 19 sumur, hanya 16 sumur yang dapat diperbaiki dan difungsikan kembali, 3 sumur lainnya tidak dapat diperbaiki karena lubang sumur yang sudah tidak ada.

Nilai pressure head yang paling rendah terjadi pada sumur SD 16 dengan nilai -22,69
$\mathrm{mH}_{2} \mathrm{O}$ dan yang paling tinggi terjadi pada sumur SD 10 dengan nilai $10,51 \mathrm{mH}_{2} \mathrm{O}$. Ratarata nilai pressure head pada tahun 2029 adalah -6,48 $\mathrm{mH}_{2} \mathrm{O}$. Nilai total head yang paling rendah terjadi pada sumur SD 20 dengan nilai $153,33 \mathrm{mH}_{2} \mathrm{O}$ dan yang paling tinggi terjadi pada sumur SD 5 dengan nilai $247,75 \mathrm{mH}_{2} \mathrm{O}$. Rata-rata nilai total head pada tahun 2029 adalah 207,68 $\mathrm{mH}_{2} \mathrm{O}$. Kedalaman muka airtanah yang terendah terjadi pada sumur SD 5 dengan nilai $77,77 \mathrm{~m}$ dan tertinggi terjadi pada sumur SD 20 dengan nilai 129,64 m. Rata-rata kedalaman muka airtanah adalah $102,08 \mathrm{~m}$.

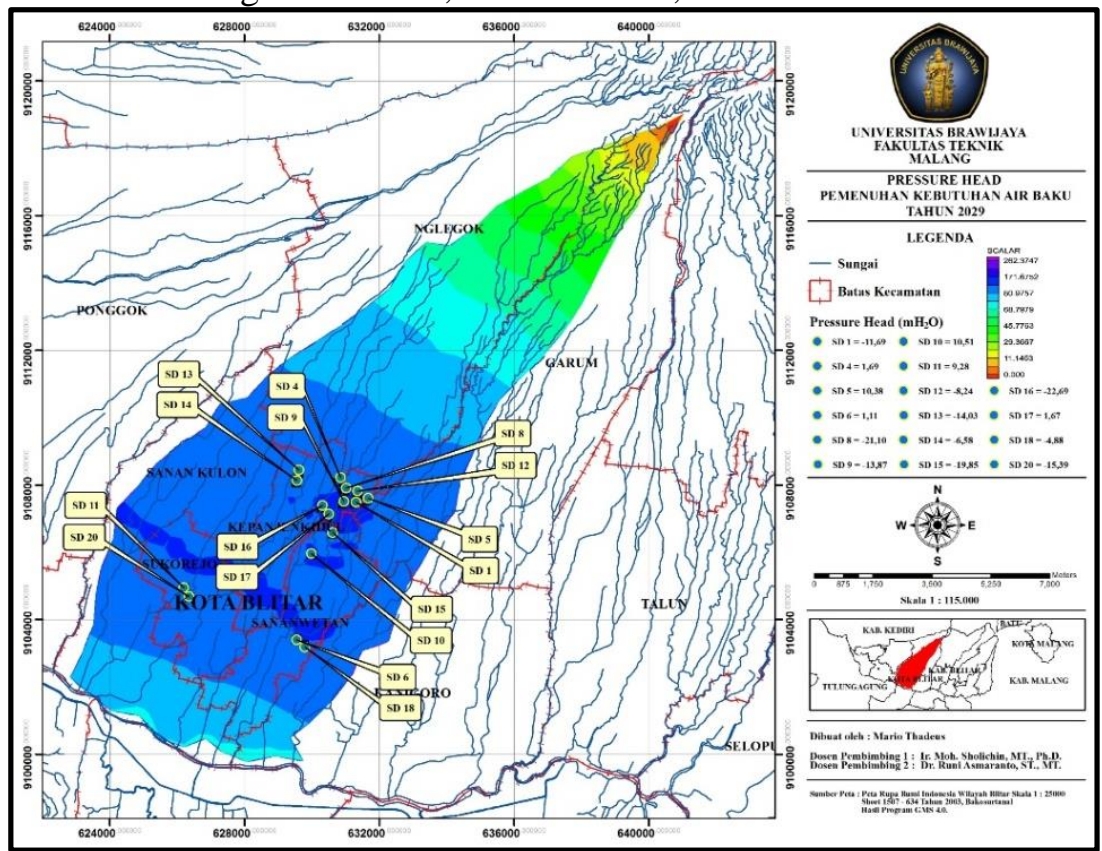

Gambar 10. Peta Sebaran Pressure Head Pemenuhan Keb. Air Tahun 2029

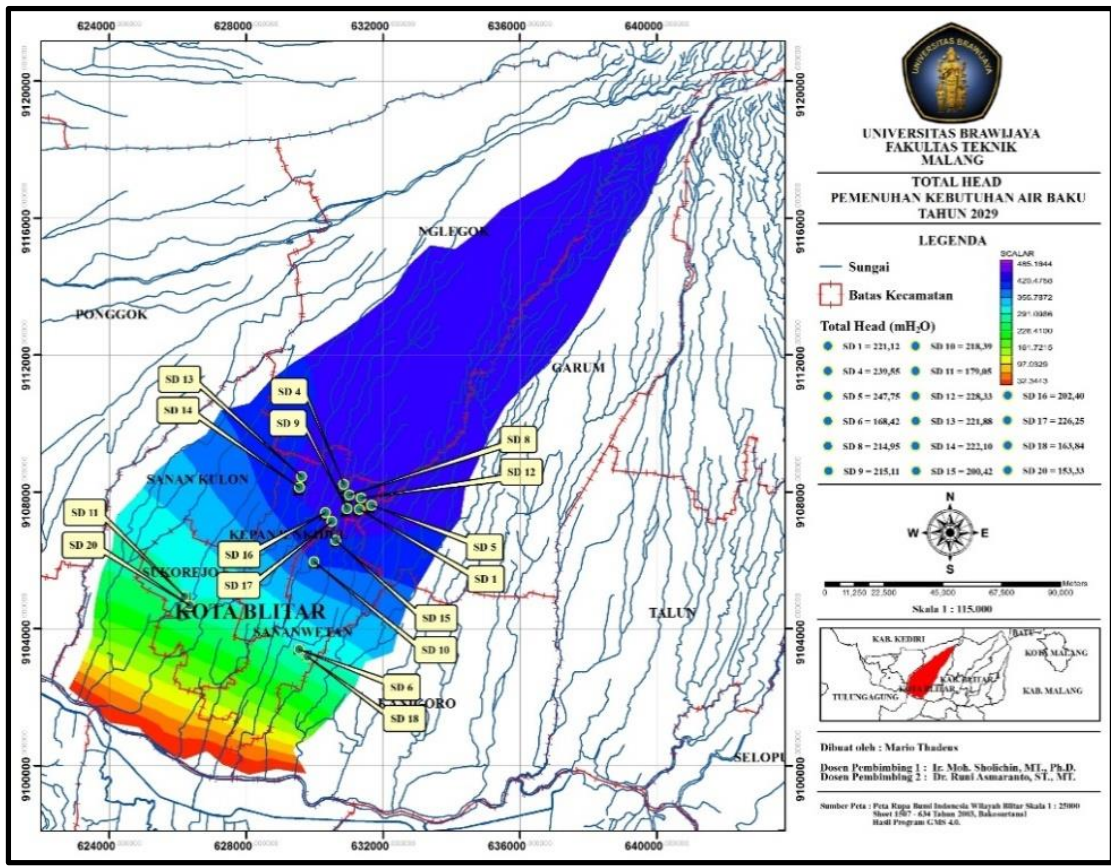

Gambar 11. Peta Sebaran Total Head Pemenuhan Keb. Air Tahun 2029 


\section{Simulasi Model GMS 4.0. Dengan Debit Sumur Optimal}

Berdararkan hasil sumulasi pemodelan GMS 4.0. didapatkan debit optimal yang ditanggung oleh sumur-sumur bor di Kota Blitar agar tidak mengakibatkan penurunan muka airtanah yang ekstrim pada sumur-sumur bor lainnya adalah sumur SD $1=15,00 \mathrm{lt} / \mathrm{dt}$, SD $4=20,00 \mathrm{lt} / \mathrm{dt}$, SD $5=19,00 \mathrm{lt} / \mathrm{dt}$, SD $6=$ $17,00 \mathrm{lt} / \mathrm{dt}, \mathrm{SD} 8=15,00 \mathrm{lt} / \mathrm{dt}, \mathrm{SD} 9=17,00$ $\mathrm{lt} / \mathrm{dt}$, SD $10=18,00 \mathrm{lt} / \mathrm{dt}$, SD $11=17,00 \mathrm{lt} / \mathrm{dt}$, SD $12=18,00 \mathrm{lt} / \mathrm{dt}$, SD $13=18,00 \mathrm{lt} / \mathrm{dt}$, SD 14 $=18,00 \mathrm{lt} / \mathrm{dt}, \mathrm{SD} 15=16,00 \mathrm{lt} / \mathrm{dt}, \mathrm{SD} 16=$ $16,00 \mathrm{lt} / \mathrm{dt}$, SD $17=17,00 \mathrm{lt} / \mathrm{dt}, \mathrm{SD} 18=15,00$ $\mathrm{lt} / \mathrm{dt}$, dan SD $20=16,00 \mathrm{lt} / \mathrm{dt}$.
Nilai pressure head yang paling rendah terjadi pada sumur SD 4 dengan nilai 41,71 $\mathrm{mH}_{2} \mathrm{O}$ dan yang paling tinggi terjadi pada sumur SD 18 dengan nilai $66,57 \mathrm{mH}_{2} \mathrm{O}$. Ratarata nilai pressure head adalah $51,86 \mathrm{mH}_{2} \mathrm{O}$. Nilai total head yang paling rendah terjadi pada sumur SD 6 dengan nilai $219,11 \mathrm{mH}_{2} \mathrm{O}$ dan yang paling tinggi terjadi pada sumur $\mathrm{SD}$ 17 dengan nilai $290,85 \mathrm{mH}_{2} \mathrm{O}$. Rata-rata nilai total head adalah 266,02 $\mathrm{mH}_{2} \mathrm{O}$. Kedalaman muka airtanah yang terendah terjadi pada sumur SD 17 dengan nilai $36,59 \mathrm{~m}$ dan tertinggi terjadi pada sumur SD 18 dengan nilai $50,76 \mathrm{~m}$. Rata-rata kedalaman muka airtanah adalah $43,74 \mathrm{~m}$.
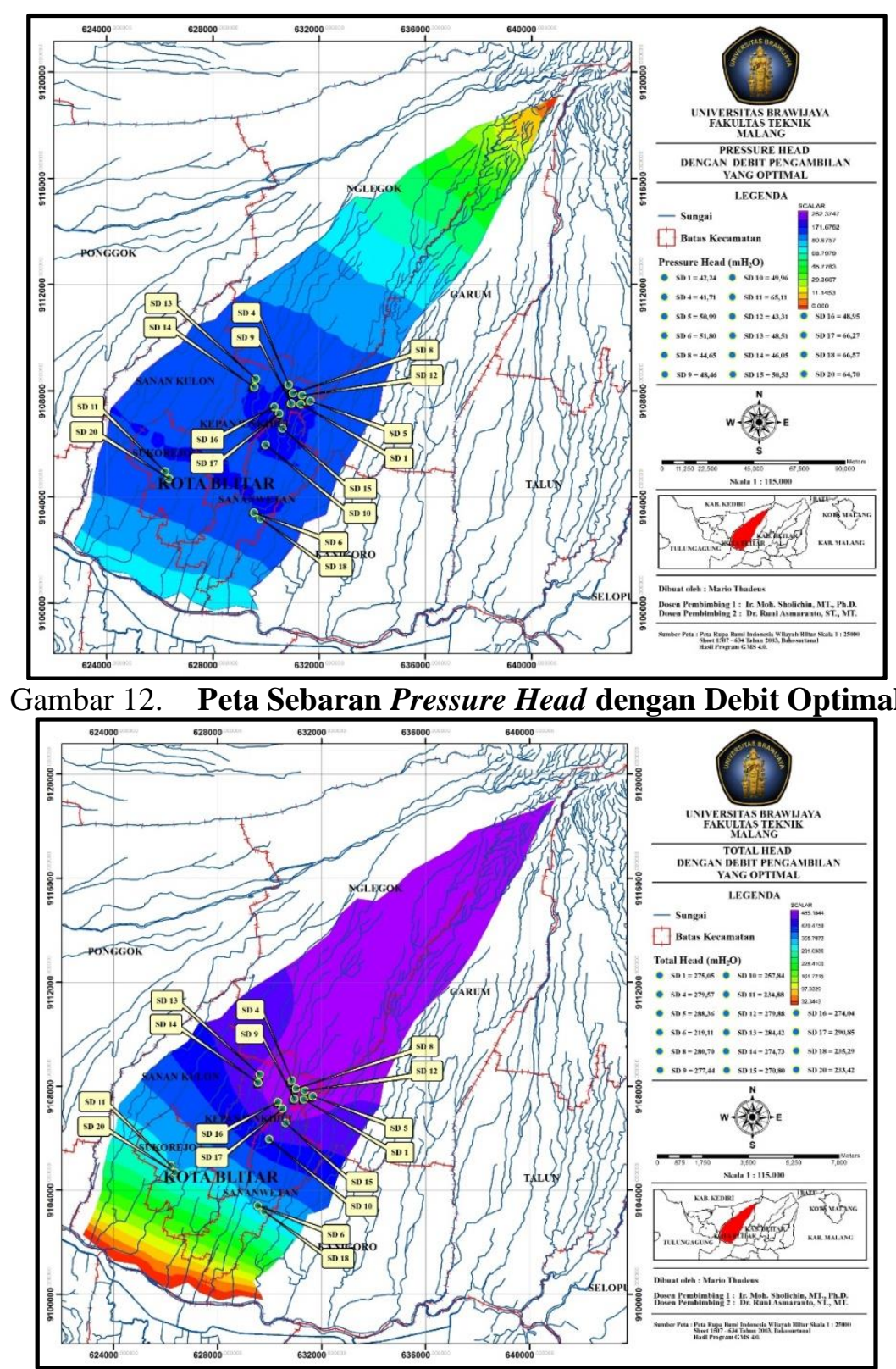

Gambar 13. Peta Sebaran Total Head dengan Debit Optimal 


\section{Upaya Konservasi Terhadap Airtanah}

1. Kebijakan konservasi yang dibutuhkan di lokasi studi dalam jangka pendek atau 5 tahun kedepan adalah melakukan perbaikan sumur-sumur bor yang masih berfungsi maupun yang sudah tidak berfungsi lagi dengan bentuk kegiatan melakukan perbaikan dan penggantian screen sumur yang telah rusak dan jebol, Pembangunan dan perbaikan kembali rumah jaga pada sumur-sumur yang sudah tidak berfungsi lagi, dan Pembangunan WTP (Water Treatment Plant) pada sumur-sumur bor yang masih berfungsi maupun yang sudah tidak berfungsi lagi.

2. Kebijakan konservasi yang dibutuhkan di lokasi studi dalam jangka menegah atau 10 tahun kedepan adalah memanfaatkan mata air Rambut Monte dan mata air Dandang untuk memenuhi kebutuhan air baku di Kota Blitar dengan bentuk kegiatan PDAM Kota Blitar bekerja sama dengan Kabupaten Blitar dalam pemanfaatan mata air Rambut Monte dan mata air Dandang, serta membangun tampungan dan jalur pipa pada mata air Rambut Monte dan mata air Dandang. Bentuk kebijakan konservasi yang kedua adalah perencanaan sumur resapan pada tiap rumah di Kota Blitar dengan bentuk kegiatan sosialisasi kepada masyarakat mengenai pentingnya meresapkan air sebanyak-banyaknya ke dalam tanah. Dan bentuk kebijakan konservasi yang ketiga adalah kebijakan mengenai batas debit maksimum yang ditanggung oleh tiap sumur bor dalam pemanfaatannya untuk memenuhi kebutuhan air baku di Kota Blitar dengan bentuk kegiatan melakukan pembatasan debit pengambilan dari masing-masing sumur.

3. Kebijakan konservasi yang dibutuhkan di lokasi studi dalam jangka panjang atau 15 tahun kedepan adalah menjaga tinggi muka air pada sungai dengan bentuk kegiatan mempertahankan kawasan resapan airtanah sebagai zona imbuhan dengan cara mempertahankan luasan area hutan pada daerah hulu, perencanaan sistem drainase resapan pada lahan pertanian maupun pemukiman dan perencanaan sumur resapan pada tiap rumah di Kota Blitar dan pembuatan peraturan daerah mengenai pembangunan sumur resapan pada tiap rumah di Kota Blitar. Bentuk kebijakan konservasi yang kedua adalah pembuatan embung sebagai alternatif penyediaan air baku di Kota Blitar dengan bentuk kegiatan merencanakan dan membangun embungembung di daerah hulu.

\section{KESIMPULAN}

Berdasarkan hasil dan pembahasan di atas, didapatkan kesimpulan sebagai berikut:

1. Debit yang dikeluarkan oleh sumur PDAM Kota Blitar untuk memenuhi kebutuhan air bersih penduduk Kota Blitar berdasarkan perhitungan kebutuhan air bersih hingga tahun 2029 sebesar 372,40 lt/dt.

2. Sebaran pressure head dan total head serta kedalaman muka airtanah pada daerah studi adalah pada tahun 1996, sumur SD 1, SD 2, SD 3, dan SD 4 sudah tidak berfungsi lagi karena nilai pressure head dan kedalaman muka airtanah yang berada di bawah screen bawah sumur. Ini disebkan karena pembangunan sumur baru yaitu sumur SD 7 dan SD 8. Pada tahun 2009, sumur SD 6, SD 7, SD 8, SD 9, SD 11, SD 12, SD 13, SD 15, dan SD 16 sudah tidak berfungsi lagi karena nilai pressure head dan kedalaman muka airtanah yang berada di bawah screen bawah sumur. Ini disebkan karena pembangunan sumur baru yaitu sumur SD 10, SD 14, SD 17, SD 18, dan SD 20.

Untuk pemenuhan kebutuhan air di tahun di tahun 2029 terdapat 10 sumur yang memiliki nilai pressure head di bawah screen bawah sumur yaitu sumur SD 1, SD 8, SD 9, SD 12, SD 13, SD 14, SD 15, SD 16, SD 18, dan SD 20.

3. Debit optimal yang ditanggung oleh sumur bor di Kota Blitar agar tidak mengakibatkan penurunan muka airtanah yang ekstrim pada sumur bor lainnya adalah debit maksimal ditanggung oleh sumur SD 5 sedangkan debit minimal ditanggung oleh sumur SD 1, SD 8, dan SD 18.

4. Upaya konservasi terhadap keberadaan airtanah di lokasi studi yang dapat dilakukan adalah memanfaatkan mata air Rambut Monte dan mata air Dandang untuk memenuhi kebutuhan air baku di Kota Blitar, perencanaan sumur resapan pada tiap rumah di Kota Blitar, kebijakan mengenai batas debit maksimum yang ditanggung oleh tiap sumur bor dalam pemanfaatannya untuk memenuhi kebutuhan air di Kota Blitar, dan pembuatan embung sebagai 
alternatif penyediaan air baku di Kota Blitar.

\section{DAFTAR PUSTAKA}

Anonim. 1994. Kriteria Perencanaan Ditjen Cipta Karya Dinas PU. Jakarta: Dinas Pekerjaan Umum.

Anonim. 2015. Kota Blitar Dalam Angka Tahun 2015. Blitar: Badan Pusat Statistik Kota Blitar.

Arsyad, Sitanala. 2006. Konservasi Tanah dan Air. Bogor: Institut Pertanian Bogor.

Bisri, Muhammad. 2012. Air Tanah. Malang: Universitas Brawijaya Press.

Kodoatie, Robert J. 2012. Tata Ruang Air
Tanah. Yogyakarta: Andi Offset.

Muliakusumah, Sutarsih. 2000. Proyeksi Penduduk. Jakarta: Fakultas Ekonomi Universitas Indonesia.

Sholichin, Mohammad. 2011. Nutrient Load Assessment in Brantas Basin using the SWAT Model. Disertasi tidak dipublikasikan. Kuala Lumpur: Faculty of Engineering University of Malaya.

The Department of Defense. 1999. Groundwater Modeling System. Reference Manual. Provo, Utah USA: Brigham Young University. 